\title{
Parenteral versus enteral potassium suppletion in icu patients: does it make a difference?
}

\author{
L Hessels $^{1 *}$, A Oude Lansink', M Hoekstra ${ }^{2}$, W Bult ${ }^{1,3}$, W M W Nijsten ${ }^{1}$ \\ From ESICM LIVES 2015 \\ Berlin, Germany. 3-7 October 2015
}

\section{Introduction}

Hypokalemia is a common electrolyte disturbance in the ICU, which makes potassiumchloride $(\mathrm{KCl})$ suppletion a frequent necessity. Parenteral $\mathrm{KCl}$ suppletion is mostly used in critically ill patients, but it is associated with safety risks, such as overcorrection and line-infections. Enteral $\mathrm{KCl}$ suppletion could be a safe and effective alternative in many instances. However, it is not known whether bioavailability of enterally administered $\mathrm{KCl}$ is sufficient in critically ill patients. Renal potassium excretion (RPE) was used as a measure of absorbed $\mathrm{KCl}$.

\section{Objectives}

To compare the RPE in patients receiving parenteral $\mathrm{KCl}$ with patients receiving enteral $\mathrm{KCl}$ during regular potassium control in the ICU.

\section{Methods}

This study was a prospective, observational study from February to March 2015, evaluating all patients with a minimal length of ICU-stay of 3 days in a university teaching hospital. Potassium was regulated by our validated computerized potassium regulation protocol, GRIP-II ${ }^{1}$. KCl-rate was advised by GRIP-II and the administration route (parenteral or enteral) was decided and recorded by an ICU nurse. $\mathrm{KCl}$ was never given as bolus neither intravenously nor enterally.

Based on $\mathrm{KCl}$ administration route, patients were assigned to either the enteral or parenteral group per day. If patients received both enteral and parenteral $\mathrm{KCl}$ on the same day were excluded from analysis, as were days when patients received renal replacement therapy. RPE was determined in 24-hour urines and compared between the enteral and parenteral group. The use of diuretics was recorded as well.

\section{Results}

A total of $101 \mathrm{ICU}$ patients with altogether $678 \mathrm{ICU}$ days were included. In 49 (49\%) patients only parenteral $\mathrm{KCl}$ was supplied and in $27(27 \%)$ only enteral $\mathrm{KCl}$ was supplied. During 376 ICU days, potassium was administered intravenously and for 302 ICU days enterally. Mean \pm SD plasma potassium was $4.1 \pm 0.4$ and $4.1 \pm$ $0.4 \mathrm{mmol} / \mathrm{L}$ in these groups. The use of diuretics per day was slightly higher in the enteral group (120 enteral, 112 parenteral; $\mathrm{p}=0.007)$. We collected 534 (79\%) RPE measurements. RPE was $65 \pm 33$ for the parenteral group and $72 \pm 35 \mathrm{mmol} / \mathrm{d}$ for the enteral group $(\mathrm{p}=0.022)$. Upon multivariate analysis with ICU day, diuretic use, plasma potassium, plasma creatinine and mode of $\mathrm{KCl}$ administration as variables, mode of $\mathrm{KCl}$ administration was not related with RPE.

\section{Conclusions}

Enteral $\mathrm{KCl}$ has a bioavailability similar to parenteral $\mathrm{KCl}$ in ICU patients.

On the basis of these observations we plan a RCT to assess the effect of the optimal mode of $\mathrm{KCl}$ administration in critically ill patients.

\section{Authors' details}

'University of Groningen, University Medical Center Groningen, Department of Critical Care, Groningen, Netherlands. ${ }^{2}$ University of Groningen, University Medical Center Groningen, Department of Anesthesiology, Groningen, Netherlands. 'University of Groningen, University Medical Center Groningen, Department of Clinical Pharmacy and Pharmacology, Groningen, Netherlands. 


\section{Reference}

1. Hoekstra M, Vogelzang M, Drost JT, et al: Implementation and evaluation of a nurse centered computerized potassium regulation protocol in the intensive care unit - a before and after analysis. BMC Med Inform Decis Mak 2010, 10(5)

doi:10.1186/2197-425X-3-S1-A182

Cite this article as: Hessels et al:: Parenteral versus enteral potassium suppletion in icu patients: does it make a difference? Intensive Care Medicine Experimental 2015 3(Suppl 1):A182.

\section{Submit your manuscript to a SpringerOpen ${ }^{\circ}$ journal and benefit from:}

- Convenient online submission

- Rigorous peer review

- Immediate publication on acceptance

- Open access: articles freely available online

- High visibility within the field

- Retaining the copyright to your article

Submit your next manuscript at $\gg$ springeropen.com 